УДК 711.168

DOI https://doi.org/10.32838/2663-5941/2020.4/37

Василишин Я.В.

Івано-Франківський національний технічний університет нафти і газу

\title{
НАПРЯМИ ДОСЛІДЖЕННЯ ЕСТЕТИЧНОГО УПОРЯДКУВАННЯ АРХІТЕКТУРНО-ЛАНДШАФТНОГО СЕРЕДОВИЩА
}

У статті узагальнено сучасне розуміння естетичного упорядкування рекреаційних ландшафтів та архітектурно-ландмафтної організачії міських просторів. Сформульовано нові напрями і наукові підходи до дослідження естетики й організації ландмафту, розробки принципів проєктування архітектурно-ландшафтного середовища, які дадуть змогу удосконалити композиційно-планувальну й функиіональну структуру міста загалом. Визначено три основні напрями досліджень: 1) вивчення ландшафту як естетичного об 'єкта; 2) вивчення людини як суб'єкта та об 'єкта естетичного сприйняття; 3) пізнання закономірностей естетичного сприйняття ландшафту людиною. Розглянуто основні підходи до естетико-ландшафтних досліджень: якісний, суб'єктивно-описовий, нейропсихологічний, просторово-нормативний, географічний, психолого-емпіричний, психолого-феноменальний. Обтрунтовано основні композищійні принципи проєктування ландшафтного середовища: планувальні (иілісність архітектурно-ландшафтного середовища, функиіональна варіативність, диференціація ландшафтів, збереження і перетворення ландшафтів) та об’ємно-просторові (співмасштабність архітектурних і ландшафтних компонентів середовища, рівновага міського силуету, видовищність архітектурно-ландшафтного середовища). Узагальнено основні естетичні категорії в їх застосуванні до ландшафту. Обгрунтовано зміст та рекомендації для завдань ландшафтного планування, ландшафтного проєктування та дизайну. Подано приклад реалізаиї̈ пошуково-навчального проєктування в галузі ландшафту на кафедрі архітектури та містобудування Івано-Франківського національного технічного університету нафти і газу, а саме «Структурно-функціональна та архітектурно-планувальна реорганізація та розвиток території Дністровського каньйону».

Ключові слова: естетичне упорядкування, ландшафт, архітектурно-ландшафтне середовище, ландшафтно-екологічна реконструкиія, міський простір.

Постановка проблеми. Як свідчить зарубіжний і вітчизняний досвід, найкращим методом оновлення архітектурно-ландшафтного середовища $є$ процес комплексного оновлення архітектурних об'єктів і середовища, в якому вони існують, спрямований на підвищення економічної ефективності та покращення екологічних і архітектурно-художніх характеристик середовища.

Одним $з$ основних напрямів наукової роботи на кафедрі архітектури та містобудування Інституту архітектури, будівництва та енергетики Івано-Франківського національного технічного університету нафти і газу є дослідження естетичного впорядкування рекреаційних ландшафтів та архітектурно-ландшафтної організації міських просторів, оскільки під впливом соціально-економічних змін у суспільстві та розвитку науковотехнічного прогресу композиційно-планувальна i функціональна структури архітектурно-ландшафтного середовища безперервно змінюються.

У роботах науковців, що вивчають природне середовище, як засіб оздоровлення міського мікроклімату показано значення озеленення про- сторів міста для поліпшення гігієнічних характеристик середовища, вітрового, шумового, радіаційного режимів, іонізації і фітонізації повітря, створення мікрокліматичного комфорту для життєдіяльності людини.

Аналіз останніх досліджень і публікацій. На потребі оновлення архітектурно-ландшафтного середовища наголошувало багато вітчизняних та зарубіжних учених. Більшість робіт присвячена дослідженням питань ландшафтно-екологічної реконструкції територій міста, прийомів і методів реконструкції озеленених просторів [1;2]. Великий перелік становлять роботи, в яких ландшафт розкривається у зв'язку з дослідженням закономірностей формування міських ансамблів, питань архітектурно-ландшафтної організації міських просторів, історичного досвіду формування ландшафтних об'єктів, комп'ютерного моделювання дизайнерського підходу до вирішення багатьох проблем формування архітектурно-ландшафтного середовища $[3 ; 4 ; 5]$.

Постановка завдання. Актуальність цього дослідження зумовлена необхідністю сформувати 
нові напрями і наукові підходи до дослідження естетики й організації ландшафту, розробки принципів проєктування і комплексної реновації архітектурно-ландшафтного середовища, які дадуть змогу удосконалити композиційно-планувальну й функціональну структури міста загалом.

Завдання дослідження - окреслити коло проблем і розробити основні композиційні принципи проєктування архітектурно-ландшафтного середовища, обгрунтувати напрями дослідження естетичного впорядкування рекреаційних ландшафтів.

Виклад основного матеріалу дослідження. Серед основних видів дослідження ландшафтів відзначимо: 1) містобудівні дослідження; 2) географічні дослідження; 3) ландшафтознавчі дослідження.

У центр уваги наукових підходів до дослідження естетики й організації ландшафту ставлять вивчення закономірностей естетичного сприйняття людиною ландшафту. Ця загальна структура визначає три основні напрями досліджень, а саме: 1) вивчення ландшафту як естетичного об' єкта; 2) вивчення людини як суб'єкта та об'єкта естетичного сприйняття; 3) пізнання закономірностей естетичного сприйняття ландшафту людиною. Ці напрями умовно можна назвати ландшафтоцентричними, антропоцентричними і перцепційними.

Ландшафтоцентричний напрям дослідження естетики ландшафту спрямований на вивчення тих рис ландшафту, які визначають його естетичні якості, їх просторову композицію. Саме 3 вивчення цих питань і почалося формування естетики ландшафту як наукового напряму.

Важливою прикладною проблемою, розробку якої можна віднести до ландшафтоцентричного напряму естетики ландшафту, $є$ наукове обгрунтування проєктів і планів естетичного упорядкування рекреаційних ландшафтів.

Антропочентричний напрям дослідження естетики ландшафту спрямований на пізнання людини, яка розглядається і як суб'єкт естетичного сприйняття ландшафту, і як об'єкт, у свідомості якого формується відповідний образ ландшафту.

Периепиійний напрям дослідження естетики ландшафту скерований на пізнання процесу, закономірностей і чинників естетичного сприйняття людиною ландшафту. Це сприйняття $є$ надзвичайно складним процесом.

Естетико-ландшафтознавчі дослідження, порівняно із дослідженнями традиційних природ- ничих напрямів ландшафтознавства, зумовлюють необхідність залучення низки підходів і методів суміжних наук (ландшафтознавства, ландшафтної екології, урбоекології та містобудівництва, рекреаційної географії, психології, соціології, культурології, дизайну).

Розглянемо основні підходи до естетико-ландшафтознавчих досліджень:

1) якісний підxід до естетико-ландшафтознавчих досліджень не вимагає пошуку краси через формальні співвідношення ознак ландшафту, а виходить із тези, що естетичними якостями ландшафт наділяє людина. Одним із поширених прийомів таких досліджень в естетиці ландшафту є опитування людей щодо їх сприйняття ландшафту, яке проводиться серед різних груп респондентів (мешканців певного регіону, людей певних соціальних груп, туристів тощо). Одержані оцінки обробляються за допомогою статистичних методів. Ці методи дають змогу отримати об'єктивні оцінки естетичності ландшафту, причому чим більша вибірка опитаних респондентів, тим загальний результат є об'єктивнішим і достовірнішим;

2) суб'єктивно-описовий підхід відрізняється від якісного тим, що оцінка та опис естетичних якостей ландшафту дається не вибіркою респондентів, а одним фахівцем. Результати таких досліджень суттєво залежать від особистих естетичних уподобань, знань і досвіду виконавця - експерта;

3) нейропсихологічні підходи на практиці реалізуються методами та прийомами відповідних розділів медицини. Тут одержано чимало результатів, які є важливими для пояснення низки особливостей сприйняття людиною ландшафту;

4) просторово-нормативний підхід до естетико-ландшафтознавчого аналізу базується на вивченні окремих естетичних характеристик ландшафту з упорядкуванням вихідного ландшафту згідно з вимогами та стандартами певного художнього стилю, діючими правилами та нормами;

5) географічний підхід полягає в дослідженні переважно значних за розмірами територій, які включають ландшафти різних фізіономічних типів;

6) психолого-емпіричний підхід відрізняється від розглянутих вище тим, що основну увагу зосереджує не на ландшафті як об'єкті естетичного сприйняття, а на людині, яка цей ландшафт сприймає, iї емоційних реакціях від сприйняття ландшафту, впливі наявних стереотипів на це сприйняття тощо; 
7) в основі психолого-феноменологічного niдxодy лежить не емпіричний матеріал наукових досліджень, а естетичні почуття, враження та оцінки конкретної особи.

Отже, естетико-ландшафтознавчі дослідження грунтуються на різних підходах. Кожний із цих підходів має як свої переваги, так і обмеження.

До основних композиційних принципів проєктування архітектурно-ландшафтного середовища слід відносити планувальні та об'ємнопросторові.

Блок планувальних принципів становлять: a) принципи цілісності архітектурно-ландшафтного середовища, які полягають у створенні на основі історично сформованих ландшафтних об'єктів системи окремих ландшафтно-архітектурних комплексів, кожний $з$ яких є самостійною закінченою архітектурно-містобудівною одиницею i входить до загальноміського ансамблю, об'єднаного спільною концепцією розвитку архітектурних і ландшафтних об'єктів; б) принципи функціональної варіативності - це організація на території міста різних типів багатофункціональних та спеціалізованих ландшафтно-архітектурних комплексів; в) принцип диференціації ландшафтів полягає у виділенні в структурі міста ландшафтних територій, що відповідають за стабілізацію і формування екологічного балансу території, і ландшафтних об'єктів, що впливають лише на формування естетичної виразності, тобто на диференціювання ландшафтних об'єктів за еколого-естетичними властивостями та характером і тривалістю використання; г) збереження і перетворення ландшафтів.

Для формування просторових візуальних 3в' язків між усіма ландшафтними об' єктами необхідна організація чіткої системи композиційних осей пішохідних площ і вулиць, бульварів, скверів, набережних і т.д. 3 високим рівнем дизайну середовища. Ця система композиційно-планувальних осей з візуальними домінантами на їх завершенні й перетині дасть змогу штучно спрямувати погляд людини саме туди, де вона зможе побачити природні компоненти архітектурно-ландшафтного середовища. Роль таких композиційних осей переважно відводиться річкам, бульварам та проспектам, вздовж яких розміщуються ландшафтноархітектурні комплекси.

У процесі розвитку архітектурної та містобудівної теорії було багато спроб розробити типологію архітектурно-ландшафтного середовища міста. В основу типології закладено найхарактерніші властивості: зміст функціональних процесів, стильову приналежність, культурно-історичну цінність, соціальну значущість, роль території у формуванні екологічного балансу чи естетичної виразності міста, а також тривалість і періодичність користування територією [1; 5].

У процесі реалізації принципу диференціації ландшафтних територій можливі три ситуації: 1) ландшафтні об'єкти щоденного використання - незначна площа, найвищий рівень дизайну середовища, будь-який метод організації ландшафту; 2) ландшафтні об’єкти періодичного тривалого відпочинку - високий рівень дизайну середовища 3 переважанням природних засобів ландшафтного дизайну, велика площа території, пейзажний або змішаний метод організації ландшафту (центральний міський парк, спеціалізовані парки, пляжі, зони активного відпочинку в лісопарках тощо); 3) ландшафтні об'єкти періодичного короткочасного відвідування - мінімальний рівень дизайну середовища, дуже велика площа території, виключно пейзажний метод організації ландшафту (великі лісопаркові масиви на периферії міста, віддалені райони санітарно-захисних $30 \mathrm{і} \mathrm{т.} \mathrm{ін.).}$

Відповідно до різних естетичних теорій один і той самий ландшафт може розглядатися як естетичний чи як позбавлений будь-яких естетичних якостей. До ландшафтних об'єктів, що впливають на естетичну виразність архітектурно-ландшафтного середовища, належать сади на дахах, ландшафтні зони в складі багатофункціональних ландшафтно-архітектурних комплексів 3 високим рівнем урбанізації, сквери, набережні тощо.

До ландшафтних об'єктів, що впливають на стан екологічної ситуації, належать лісопарки, гідро- та лугопарки, історичні ландшафти, значні за площею ландшафтно-архітектурні комплекси.

До блоку об'ємно-просторових принципів проєктування і реновації архітектурно-ландшафтного середовища належать принципи співмасштабності архітектурних і ландшафтних компонентів середовища (розміри забудованих територій мають бути співмасштабними до площі навколишніх відкритих ландшафтних просторів), рівноваги міського силуету (базується на поступовій трансформації моноцентричної структури міського каркасу, що спирається на домінування ролі історичного центру) та видовищності архітектурно-ландшафтного середовища (полягає в тому, що архітектурно-ландшафтне середовище розвивається як видовище, спрямоване на збудження сильних емоцій). 
Серед основних теорій ландшафтознавства виділимо: 1) дистанційні теорії, які обстоюють положення, що естетичне відчуття можливе лише від об'єктів, які не мають для людини утилітарного, практичного значення; 2) теорії задіяності естетичного сприйняття, яке виникає в людини в результаті іiі інтенсивного та глибокого «занурення» в певний об'єкт, пізнання цього об'єкта через щоденну практику; 3) суб'єктивістські теорії естетики, що наголошують на провідній ролі суб'єкта в естетичному сприйнятті; 4) найбільший інтерес для ландшафтознавства становлять об 'єктивістські теорії естетики, які досить різноманітні, і серед них можна виділити три групи: а) імітаційні; б) емоційні; в) формалістські.

Розглянемо основі естетичні категорії в їх застосуванні до ландшафту.

Естетичне розглядається як вихідна категорія естетики, як загальна характеристика ії інших категорій. Статус естетичного залежить не лише від об'єкта, але від аспекту та способу його пізнання власне естетичного, а не якогось іншого (морального, інтелектуального тощо) відношення до нього.

В естетиці є кілька основних інтерпретацій естетичного. Узагальнення думок з приводу естетичного в природі дає змогу вказати на існування двох тлумачень цієї категорії. Перше тлумачення називають канонічним - у природі спирається на деякий естетичний ідеал, канон; із цим каноном порівнюється природа (ландшафт) і краса природи (ландшафту), а друге - натуралістичним; зводиться до того, що саме природа, а не штучні об'єкти 3 мистецькими творами включно є первинним носієм естетичного та прекрасного.

Гармонія ландшафту може досягатися не тільки тим, що він впорядкований природними законами, а й іншими вимірами порядку. Серед цих вимірів особливе значення мають: регулярність (ритмічність), пропорційність, симетричність.

Елегантність ландшафту є частковим виразом його естетичної досконалості, коли вона виникає за якомога меншого числа елементів, місць ландшафту та композиційних зв'язків між ними.

Власне, саме елегантність лежить в основі естетичного сприйняття таких ландшафтів, як пустельні, степові, тундрові, їх не можна вважати ані мальовничими, ані величними. Гармонійність тут також здебільшого виражена слабко, оскільки для іiї повного виразу не вистачає матеріалу, різноманіття місць, кольорів тощо.

Чимало методик оцінки краси ландшафту грунтувалося на тезі: чим більш різноманітним $\epsilon$ ландшафт, тим він більш естетичний [6].
Розрізняють чотири типи ландшафтів: природні, антропогенні, техногенні та мистецькі. Кожний із них має відповідний тип краси і відповідну стратегію іiї збереження та відновлення.

Ландшафтна архітектура, таким чином, тримає в полі зору одночасно два об'єкти - ландшафт і людину. Залежно від постановки дослідницького завдання як об'єкт дослідження може розглядатися ландшафт, а людина - як суб' єкт його сприйняття, в інших випадках об'єкт і суб'єкт дослідження міняються місцями.

Ландшафтний дизайн зумовлюється уявленнями, цілісним підходом, необхідністю проєктувати не окремі об'єкти, а фрагменти архітектурноландшафтного середовища.

Подамо прикладну реалізацію пошуковонавчального проєктування в галузі ландшафту на кафедрі архітектури та містобудування.

Концепція "Структурно-функціональна та архітектурно-планувальна реорганізація та розвиток території Дністровського каньйону» трактується на основі ідей та пропозицій ландшафтнопросторової організації рекреаційних утворень, формування та розвитку екорекреаційної мережі р. Дністер. Вона містить таке:

1. У прибережній зоні доцільним $є$ створення терасових парків, гідропарків та ін. У вододільній зоні формується мережа агропарків, етнопарків, заповідних парків та ін.

Екорекреаційна мережа p. Дністер є багатою типологічною різноманітністю ландшафтних об'єктів. Деякі з них:

- агропарки - формуються на базі агроландшафтів, (агротуризм, прогулянковий, пізнавальний відпочинок);

- етнопарки - формуються на базі українського села з багатою історико-культурною спадщиною (краєзнавчий туризм, активний, пізнавальний відпочинок);

- заповідні парки - основою формування парків є охоронно-заповідні території, структурні елементи екосистеми України (краєзнавчий туризм, пізнавальний відпочинок);

- гідропарки - активний відпочинок і розваги;

- технопарки - штучне середовище комбінацій технічних пристроїв і природного оточення (активний, пізнавальний відпочинок).

2. У розвиток ідеї формування великих природно-ландшафтних територій $\epsilon$ концепція організації системи екорекреаційної мережі; пропонується створення тематичних парків, тематика яких пов'язана 3 напрямом науково-дослідних комплексів екоцентрів рекреаційного змісту. 
3. Функціональна організація рекреаційних зон: рекреаційно-бальнеологічна зона; рекреаційні об'єкти; агропаркова зона; аграрно-виробнича зона.

4. Система транспорту та обслуговування $€$ одним із найважливіших завдань загальної концепції.

Висновки. Таким чином, виходячи із завдань зміни проєктних підходів та естетизації архітектурних рішень, обгрунтовано зміст та рекомендації для задач ландшафтного планування, ландшафтного проєктування та дизайну, тобто кожного із видів ландшафтної проєктної діяльності. Успішний розвиток рекреаційних регіонів залежить від умілого використання естетичного потенціалу рекреаційного простору, який зосереджений у природних умовах, історичних характеристиках та людях, їх світоглядно-ментальній сутності, освіченості, відчутті естетичних потреб.
Згідно 3 результатами проведеного дослідження можна зробити висновок, що в процесі проєктування і комплексної реновації архітектурно-ландшафтного середовища слід виділяти два основні блоки принципів: планувальні та об'ємно-просторові. До блоку планувальних принципів належать принципи цілісності архітектурно-ландшафтного середовища, функціональної варіативності, диференціації ландшафтів, збереження i перетворення ландшафтів. Блок об'ємно-просторових принципів - це принципи співмасштабності архітектурних і ландшафтних компонентів середовища, рівноваги міського силуету та видовищності архітектурно-ландшафтного середовища. Усі принципи тісно пов'язані між собою, бо кінцевою метою їх дотримання є високоякісне середовище життєдіяльності людини.

\section{Список літератури:}

1. Сычева А.В. Архитектурно-ландшафтная среда. Минск : Вышэйшая школа, 1982. 182 с.

2. Вергунов А.Н., Денисов Н.В., Ожегов С.С. Ландшафтное проектирование. Ленинград : Стройиздат, 1994. $260 \mathrm{c}$.

3. Макухін В.Ф. Планувальна композиція сучасного міста. Київ : Будівельник, 1974. 66 с.

4. Клюшниченко Є.Є. Соціально-економічні основи планування та забудови міст. Київ : Укрбудінформ, 1999.

5. Вергунов А.П. Архитектурно-ландшафтная организация крупного города. Ленинград : Стройиздат. Ленингр. отд-ние, 1982. 135 с.

6. Фремптон К. Современная архитектура: Критический взгляд на историю развития. Москва : Стройиздат, 1990. $535 \mathrm{c}$.

\section{Vasylyshyn Ia.V. DIRECTIONS OF RESEARCH OF AESTHETIC ORDERING OF ARCHITECTURAL AND LANDSCAPE ENVIRONMENT}

The article summarizes the modern understanding of the aesthetic arrangement of recreational landscapes and architectural and landscape organization of urban spaces. New directions and scientific approaches of research of aesthetics and the organization of a landscape, development of principles of designing of the architectural and landscape environment which will allow to improve compositional-planning and functional structure of the city as a whole are formulated. There are three main areas of research: 1) the study of the landscape as an aesthetic object, 2) the study of man as a subject and object of aesthetic perception; 3) knowledge of the laws of aesthetic perception of the landscape by man. The main approaches of aesthetic and landscape research are considered: qualitative, subjective-descriptive, neuropsychological, spatial-normative, geographical, psychological-empirical, psychological-phenomenal. The basic compositional principles of landscape environment design are substantiated: planning (integrity of architectural-landscape environment, functional variability, differentiation of landscapes, preservation and transformation of landscapes) and spatial-spatial (co-scale of architectural and landscape components of environmental environment, force environment). The main aesthetic categories in their applic ation to the landscape are generalized. The content and recommendations for the tasks of landscape planning, landscape design and design are substantiated. An example of research and educational design in the field of landscape at the Department of Architecture and Urban Planning of Ivano-Frankivsk National Technical University of Oil and Gas, namely: "Structuralfunctional and architectural-planning reorganization and development of the Dniester canyon".

Key words: aesthetic arrangement, landscape, architectural-landscape environment, landscape-ecological reconstruction, urban space. 